\title{
$\beta$-mannanase and mannan oligosaccharides in broiler chicken feed
}

\author{
$\beta$-mananase e mananoligossacarídeo em rações de frangos de corte
}

\author{
Victor Ramos Sales Mendes de Barros ${ }^{\mathrm{I}}$ Geraldo Roberto Quintão Lana ${ }^{\mathrm{I}}$ \\ Sandra Roselí Valerio Lana ${ }^{I}$ Ângela Maria Quintão Lana ${ }^{I I}$ Fabio Sales Albuquerque Cunha ${ }^{\text {II }}$ \\ João Virgínio Emerenciano NetoII
}

\begin{abstract}
The study aimed to evaluate the use of $\beta$-mannanase and mannan oligosaccharides (MOS) to replace growth promoters in broiler diets. Four hundred male Cobb broiler chicks were used, with initial weight of $45 \pm 1 \mathrm{~g}$, distributed in a completely randomized design with five treatments and eight repetitions of ten birds. The treatments were: basal feed; basal feed without growth promoter; basal feed without growth promoter $+\beta$-mannanase; basal feed without growth promoter + MOS; and basal feed without growth promoter $+\beta$-mannanase + MOS. The feed intake of the birds increased in response to dietary treatments compared to basal diet during the period 1-21 days of age. A higher weight gain and improved feed conversion was found at 42 days of age among birds that had received the basal diet without growth promoter + MOS. The absolute weight at slaughter, relative carcass and prime cuts except breast weights improved in response to dietary treatments compared to the basal diet at 42 days of age. No difference was observed in relative weight of the liver, while significant differences were found in the weight of heart, gizzard, and abdominal fat. It was concluded that $\beta$-mannanase and MOS can replace the growth promoters in broiler diets without compromising production and economic performance. However, the association of these products into the feed may cause negative interaction that reduces the broiler chickens' performance.
\end{abstract}

Key words: broiler chickens, economic efficiency, exogenous enzymes.

\section{RESUMO}

O experimento teve como objetivo avaliar a utilização de $\beta$-mananase e mananoligossacarídeos em substituição aos promotores de crescimento nas rações para frangos de corte. Foram utilizados 400 pintos de corte machos da marca Cobb, com peso inicial de $45 \pm 1 \mathrm{~g}$, distribuídos em delineamento inteiramente ao acaso, com cinco tratamentos e oito repetições de 10 aves.
Os tratamentos foram: ração basal; ração basal sem promotor de crescimento; ração basal sem promotor de crescimento + $\beta$-mananase; ração basal sem promotor de crescimento + MOS; e ração basal sem promotor de crescimento $+\beta$-mananase + MOS. O consumo de ração das aves aumentou em resposta aos tratamentos dietéticos, quando comparados à ração basal no período de 1 a 21 dias de idade. Observou-se maior ganho de peso e melhora na conversão alimentar das aves aos 42 dias de idade que receberam a dieta basal sem promotor de crescimento + MOS. Os pesos absolutos ao abate e relativos de carcaça e de cortes nobres, com exceção de peito, melhoraram em resposta aos tratamentos dietéticos, quando comparados à ração basal aos 42 dias de idade. Não houve diferença sobre o peso relativo de fígado, enquanto os pesos de coração, moela e gordura abdominal foram influenciados pelos tratamentos. Concluiu-se que a $\beta$-mananase e o MOS podem substituir os promotores de crescimento em rações de frangos de corte sem comprometer o desempenho produtivo $e$ econômico, no entanto, a associação destes produtos à ração pode causar interação, reduzindo o desempenho das aves.

Palavras-chave: aves, eficiência econômica, enzimas exógenas.

\section{INTRODUCTION}

Advances in poultry production in the past few years, mainly in broiler production, are mainly due to the adjustments arising from a series of research studies developed in various segments including genetics, adaptations in facilities, equipment automation, health, and nutrition.

About $80 \%$ of the birds' diets are made up of ingredients of plant origin (corn and soy meal), containing non-starch polysaccharides (NSPs) that

\footnotetext{
'Programa de Pós-graduação em Zootecnia, Universidade Federal de Alagoas (UFAL), Campus Delza Gitaí, 57100-000, Rio Largo, AL, Brasil. E-mail: glana@bol.com.br. *Corresponding author.

IIPrograma de Pós-graduação em Zootecnia, Universidade Federal de Minas Gerais (UFMG), Belo Horizonte, MG, Brasil.

IIIUniversidade Estadual de Alagoas (UNEAL), Santana do Ipanema, AL, Brasil. 
form the cell wall in plants, where a large portion of this group is present in the hemicellulose fraction. The NSPs have the characteristic of increasing gastrointestinal viscosity, which results in a reduction in the diffusion rate of digestive enzymes and substrates, preventing their interactions on the surface of the intestinal mucosa, leading to impaired digestion and absorption of nutrients. Endogenous enzymes produced by poultry and swine cannot hydrolyze the NSPs contained in cereals (OPALINSKI et al., 2010). In poultry, only the amylase enzyme produced by the pancreas can hydrolyze starch into smaller units that can be absorbed; therefore, the presence of exogenous enzymes is needed (O'NEILL et al., 2014).

The enzyme $\beta$-mannanase is responsible for the hydrolysis of $\beta$-mannans, thus reducing intestinal viscosity, promoting better nutrient digestibility, and acting on pathogens after hydrolysis. However, since the exact effect of the enzyme interaction is unknown, and there is a difficulty in determining the amount of NSPs present in foods, the results may often be controversial (ALBINO et al., 2006).

Mannan oligosaccharides (MOS) derived from the yeast cell wall have high binding affinity, providing a competitive binding site for oligosaccharide-specific bacteria. The benefits of MOS are based on properties that include changes in the intestinal flora, a reduction in mucosa turnover rate, and the modulation of the immune system in the intestinal lumen (SIMS et al., 2004). Therefore, this study aimed to evaluate the use of $\beta$-mannanase and mannan oligosaccharides (MOS) to replace growth promoters in broiler diets.

\section{MATERIAL AND METHODS}

The trial was carried out in the Aviculture Sector of the Center for Agrarian Sciences at the Federal University of Alagoas, in the city of Maceio, Brazil, during the months of August and September 2011. Four hundred one-day-old broiler chicks of the Cobb $500^{\circledR}$ breed were used, selected according to the initial weight of $45 \pm 1 \mathrm{~g}$, randomly distributed in a shed with reused sugarcane bagasse bedding, raised according to the breed manual.

The broiler chickens were allocated to a brick shed, with 40 experimental units, built on the east-west axis with a ceiling height of $3.5 \mathrm{~m}$ and natural ventilation. The climate variables were monitored daily at 9:00 AM and 4:00 PM with maximum-minimum, dry- and wet-bulb thermometers, and a black globe thermometer. The average air temperature over the trial period was $25.4^{\circ} \mathrm{C}$ (maximum and minimum temperatures of 23.2 and $27.6^{\circ} \mathrm{C}$, respectively) and $78.0 \%$ average relative air humidity. The value of 77.6 found for the black globe temperature and humidity index (BGHI) was calculated according to BUFFINGTON et al. (1981).

Feed and water were provided ad libitum in tubular feeders and hanging fountains throughout the trial. The thermal control of the animals was done with artificial heating in each box until the $14^{\text {th }}$ day with 100-watt incandescent light bulbs. Artificial illumination was provided by 60 -watt fluorescent light bulbs in a continuous light regimen.

The isonutritive and isoenergetic experimental diets based on soy meal and corn (Table 1) were formulated according to the nutritional needs of high-performance male broilers indicated by ROSTAGNO et al. (2011). Diets were subdivided into four periods: 1 to $7 ; 8$ to $21 ; 22$ to 33; and 34 to 42 days. The treatments were: T1 Basal diet (Positive Control); T2 - Basal diet without growth promoter (Negative Control); T3 - Basal diet without growth promoter $+\beta$-mannanase; T4 - Basal diet without growth promoter + MOS; T5 - Basal diet without growth promoter $+\beta$-mannanase + MOS. $\beta$-mannanase and MOS were added to the treatments replacing the inert carrier, according to the manufacturers' recommendations, i.e., $0.500 \mathrm{~kg}$ ton $^{-1} \beta$-mannanase in all raising periods and 1.500 , 1.000 , and $0.500 \mathrm{~kg} \mathrm{ton}^{-1}$ MOS for the periods of 1 to $21 ; 22$ to 33 , and 34 to 42 days of age, respectively.

The trial design was completely randomized with five treatments, eight repetitions, and ten broiler chickens per experimental unit. The statistical analyses of the assessed variables were carried out with the software SAEG version 9.0, and the averages were compared by Duncan's test at a $5 \%$ significance level. At the end of each trial period, the broiler chickens, the feeds, and the feed leftovers of each repetition were weighed to evaluate the productive performance of the broilers subjected to different treatments. At the end of the trial period, all broiler chickens were individually weighed and two birds of average weight from each trial unit were identified, individually weighed, slaughtered, plucked, and eviscerated after eight hours of fasting for analysis of the characteristics found in the carcass and cuts. The abdominal fat was composed of the fatty tissue around the cloaca and bursa of Fabricius.

The parameters assessed were: absolute weight at slaughter $(\mathrm{g})$ and relative weight $(\%)$ of carcass, prime cuts (breast, thighs, drumsticks, and wings), edible offal (heart, liver, and gizzard), and abdominal fat. After the carcasses were weighed, the 
Table 1 - Composition of basal diets used in the trial periods.

\begin{tabular}{|c|c|c|c|c|}
\hline \multirow[t]{2}{*}{ Ingredients (\%) } & \multirow[b]{2}{*}{1 to 7} & \multirow[b]{2}{*}{8 to 21} & \multirow[b]{2}{*}{22 to 33} & \multirow[b]{2}{*}{34 to 42} \\
\hline & & & & \\
\hline Corn seed & 55.509 & 57.139 & 59.107 & 63.094 \\
\hline Soy meal 46 & 24.896 & 18.261 & 10.446 & 7.007 \\
\hline Extruded soybean & 14.479 & 19.970 & 26.231 & 26.098 \\
\hline Dicalcium phosphate & 1.700 & 1.300 & 1.100 & 0.800 \\
\hline Limestone $38 \%$ & 1.300 & 1.400 & 1.300 & 1.200 \\
\hline Salt $(\mathrm{NaCl})$ & 0.530 & 0.520 & 0.490 & 0.490 \\
\hline Premix (vitamin and mineral) ${ }^{1}$ & 0.100 & 0.100 & 0.100 & 0.100 \\
\hline DL-Methionine $99 \%$ & 0.373 & 0.322 & 0.306 & 0.286 \\
\hline Lysine $\mathrm{HCl} 78.8 \%$ & 0.533 & 0.428 & 0.354 & 0.348 \\
\hline Threonine $98 \%$ & 0.080 & 0.060 & 0.066 & 0.077 \\
\hline Coccidiostat $^{2}$ & 0.040 & 0.040 & 0.030 & 0.030 \\
\hline Growth promoter ${ }^{3}$ & 0.020 & 0.020 & 0.020 & 0.020 \\
\hline Inert carrier & 0.440 & 0.440 & 0.450 & 0.450 \\
\hline Total & 100.000 & 100.000 & 100.000 & 100.000 \\
\hline Nutrients & -1----- & --------C & sition------. & ------- \\
\hline Metabolizable energy (kcal) & 2.960 & 3.050 & 3.150 & 3.200 \\
\hline Crude protein $\%$ & 22.40 & 21.20 & 19.80 & 18.40 \\
\hline Digestible lysine \% & 1.324 & 1.217 & 1.131 & 1.060 \\
\hline Digestible methionine $\%$ & 0.516 & 0.475 & 0.452 & 0.424 \\
\hline Digestible threonine $\%$ & 0.861 & 0.791 & 0.735 & 0.689 \\
\hline Digestible tryptophan $\%$ & 0.250 & 0.240 & 0.220 & 0.200 \\
\hline Calcium \% & 0.920 & 0.841 & 0.758 & 0.663 \\
\hline Available phosphorous $\%$ & 0.470 & 0.401 & 0.354 & 0.309 \\
\hline Sodium \% & 0.220 & 0.210 & 0.200 & 0.190 \\
\hline
\end{tabular}

${ }^{1}$ premix kg ${ }^{-1}$ : Vit. A 13,440,000UI; Vit. D 3,200,000UI; Vit. E 28,000mg kg-1; Vit. K 2,880mg kg ${ }^{-1}$; Thiamine 3,500mg kg ${ }^{-1}$; Riboflavin 9,600 $\mathrm{mg} \mathrm{kg}^{-1}$; Pyridoxine 5,000 $\mathrm{mg} \mathrm{kg}^{-1}$; Cyanocobalamin 19,200mcg kg-1; Folic acid 1,600 $\mathrm{mg} \mathrm{kg}^{-1}$; Pantothenic acid 25,000mg kg ${ }^{-1}$; Niacin

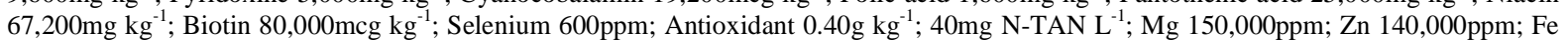
100,000ppm; Cu 16,000ppm; IodoI 1,500ppm.

${ }^{2}$ Coccidiostat: from 1 to 21 days, Nicarbazin 25\%; from 22 to 42 days, Monenzin $20 \%$.

${ }^{3}$ Growth promoter: Bacitracin $\left(100 \mathrm{~g} \mathrm{ton}^{-1}\right)$ and Colistin sulfate $\left(100 \mathrm{~g} \mathrm{ton}^{-1}\right)$.

relative weight $(\%)$ was calculated in relation to the slaughter weight (after eight hours in fasting); the yields of prime cuts, edible offal, and abdominal fat were calculated in relation to the carcass weight.

The economic analysis was carried out as a function of the live weight, feed intake, and feed cost during the treatments employed. The economic analysis is inherent to the production and feed component, since the labor and other farming expenses were the same for all treatments. The value of the live broilers was based on the value earned by the market (USD1.46 kg-1) and the value of the raw materials used for calculating the cost of the feeds was based on the values in effect on September $27^{\text {th }}$ 2011 according to the company Ave Sui Consultoria Técnica Comércio e Representações, Brazil.

In order to obtain the variables used in the economic analysis, the following parameters were considered: gross revenue (GR), which is the amount earned as a function of the live weight versus broiler price; gross margin (GM), which represents the difference between the gross income and the feeding cost; relative gross margin (RGM), which is the quotient between the gross margin of the other treatments in relation to treatment 1 (basal diet); average profitability (AP), which represents the quotient between the gross margin and the feeding cost, indicating the profitability over the investment in feed; and relative profitability index (RPI), which represents the quotient between the average profitability of the various treatments and treatment 1 . The value of 100 was assigned to the relative margin and to the relative profitability index of treatment 1 .

\section{RESULTS AND DISCUSSION}

From the results in table 2, it can be seen that the broilers' feed intake at the phase of 1 to 21 days of 
Table 2 - Effect of $\beta$-mannanase and mannan oligosaccharides on feed intake (FI), weight gain (WG), and feed conversion ratio (FCR) of male broilers from 1 to 42 days of age.

\begin{tabular}{|c|c|c|c|c|c|c|c|}
\hline Variables & $\begin{array}{l}\text { Periods } \\
\text { (days) }\end{array}$ & $\begin{array}{c}\text { Positive } \\
\text { Control (T1) }\end{array}$ & $\begin{array}{c}\text { Negative } \\
\text { Control (T2) }\end{array}$ & $\begin{array}{c}\beta \text {-mannanase } \\
\text { (T3) }\end{array}$ & MOS (T4) & $\begin{array}{c}\beta \text {-mannanase }+ \\
\text { MOS (T5) }\end{array}$ & $\mathrm{CV}(\%)$ \\
\hline \multirow{3}{*}{ FI $(\mathrm{kg})$} & 1 to $21 *$ & $1.295 \mathrm{~b}$ & $1.349 \mathrm{a}$ & $1.346 \mathrm{a}$ & $1.355 \mathrm{a}$ & $1.335 \mathrm{ab}$ & 2.72 \\
\hline & 22 to 42 & $3.779 \mathrm{a}$ & $3.667 \mathrm{a}$ & $3.771 \mathrm{a}$ & $3.728 \mathrm{a}$ & $3.671 \mathrm{a}$ & 4.05 \\
\hline & 1 to 42 & $5.073 \mathrm{a}$ & $5.016 \mathrm{a}$ & $5.118 \mathrm{a}$ & $5.083 \mathrm{a}$ & $5.006 \mathrm{a}$ & 3.04 \\
\hline \multirow{3}{*}{ WG $(\mathrm{kg})$} & 1 to 21 & $0.967 \mathrm{a}$ & $0.984 \mathrm{a}$ & $0.977 \mathrm{a}$ & $0.987 \mathrm{a}$ & $0.945 \mathrm{a}$ & 4.22 \\
\hline & 22 to $42^{*}$ & $2.057 \mathrm{ab}$ & $2.079 \mathrm{a}$ & $2.096 \mathrm{a}$ & $2.123 \mathrm{a}$ & $1.999 \mathrm{~b}$ & 5.37 \\
\hline & 1 to $42 *$ & $3.023 \mathrm{ab}$ & $3.063 \mathrm{ab}$ & $3.073 \mathrm{ab}$ & $3.109 \mathrm{a}$ & $2.944 \mathrm{~b}$ & 3.74 \\
\hline \multirow{3}{*}{ FCR $\left(\mathrm{kg} \mathrm{kg}^{-1}\right)$} & 1 to $21^{*}$ & $1.34 \mathrm{~b}$ & $1.37 \mathrm{ab}$ & $1.37 \mathrm{ab}$ & $1.37 \mathrm{ab}$ & $1.41 \mathrm{a}$ & 4.05 \\
\hline & 22 to $42^{*}$ & $1.84 \mathrm{a}$ & $1.76 \mathrm{~b}$ & $1.80 \mathrm{ab}$ & $1.76 \mathrm{~b}$ & $1.84 \mathrm{a}$ & 4.63 \\
\hline & 1 to $42 *$ & $1.67 \mathrm{~b}$ & $1.63 \mathrm{~b}$ & $1.66 \mathrm{~b}$ & $1.63 \mathrm{~b}$ & $1.70 \mathrm{a}$ & 3.19 \\
\hline
\end{tabular}

${ }^{1} \mathrm{~T} 1$ - basal feed (Positive Control); T2 - basal feed without growth promoter (Negative Control); T3 - basal feed without growth promoter + $\beta$-mannanase; T4 - basal feed without growth promoter + MOS; T5 - basal feed without growth promoter $+\beta$-mannanase + MOS.

* Significant $(\mathrm{P}<0.05)$, by $\mathrm{F}$ test.

Averages followed by different letters in the same line differ according to Duncan's test $(\mathrm{P}<0.05)$.

age was significantly higher $(\mathrm{P}<0.05)$ for the birds fed with basal feed without growth promoter + MOS (T4) compared to those fed with basal feed. Similar results were obtained by CARAMORI JR et al. (2008) when using antibiotics and MOS-based prebiotics in diets for broilers from 1 to 21 days old. On the other hand, ALBINO et al. (2006), LORENÇON et al. (2007) and ROCHA et al. (2010) observed that feed intake of the broiler chickens showed no significant differences when using antibiotics and MOS in diets for broilers.

From 22 to 42 days of age and in the whole period, feed intake was not $(\mathrm{P}>0.05)$ influenced by any treatments. Similarly, SIMS et al. (2004), GODOI et al. (2008) and SOUZA et al. (2008) reported no difference in broilers' feed intake at 42 days of age attributed to the use of MOS or antibiotics. However, ESONU et al. (2004), while studying the inclusion of cellulose enzyme in poultry feed over the period of 28 and 35 days of age, saw an increase in feed intake and decrease in weight gain due to the inclusion of the enzyme. Similarly, OPALINSKI et al. (2010) found higher feed intake of broilers fed with a diet including an enzymatic complex containing $\beta$-mannanase.

No significant difference $(\mathrm{P}>0.05)$ was seen for the broilers' weight gain between 1 to 21 days of age among the assessed treatments. Similar results were obtained by ZOU et al. (2006) and OPALINSKI et al. (2010) while feeding broilers with diets with and without $\beta$-mannanase over the period of 1 and 21 days of age.

At the phase of 22 to 42 days of age, the broilers that received the treatment with the basal diet without growth promoter + MOS (T4) had a 3.10\% significantly $(\mathrm{P}<0.05)$ higher weight gain compared to the broilers that received the treatment with basal diet $(2.057 \mathrm{~kg})$. The results suggest that the MOS used in the diets had positive effects on the intestinal mucosa and immune system, and reduced colonization by pathogenic bacteria. These results are in agreement with CARAMORI JR et al. (2008), GODOI et al. (2008) and ARRUDA et al. (2013) who reported that MOS can improve productive performance.

Over the whole rearing period, it was also seen that the birds fed with basal diet without growth promoter + MOS (T4) had significantly higher $(\mathrm{P}<0.05)$ weight gain $(3.109 \mathrm{~kg})$, followed by the treatment containing only $\beta$-mannanase $(3.073 \mathrm{~kg})$. The better performance may be associated with the stimulus to the intestinal mucosa provided by the enzyme, since it reduces intestinal viscosity, allowing for higher nutrient absorption, consequently favoring higher weight gain. These results corroborate those obtained by ZOU et al. (2006) and ALBINO et al. (2006), CARAMORI JR et al. (2008) and GODOI et al. (2008), who tested antibiotics and MOS-based prebiotics in broiler diets and saw an improvement in the broilers' weight gain. On the other hand, ESONU et al. (2004), while assessing diets with and without added cellulase enzyme, did not see an improvement in the birds' final weight or feed conversion ratio.

In the period of 1 to 21 days of age, the broilers fed with basal feed had the best feed conversion ratio $(\mathrm{P}<0.05)$ compared to the others. 
Moreover, it was seen that the broilers fed with basal feed without growth promoter $+\beta$-mannanase + MOS (T5) had the worst feed conversion ratio index (1.41), likely due to the interaction between $\beta$-mannanase and MOS.

From 22 to 42 days of age, the feed conversion ratio was influenced $(\mathrm{P}<0.05)$ by the treatments. It can be seen that the treatments with basal feed without growth promoter (T2) and with basal feed without growth promoter + MOS (T4) had the best feed conversion ratio indices (1.76) compared to the other treatments. In the period of 1 to 42 days of age, the broilers fed with basal feed without growth promoter $+\beta$-mannanase + MOS (T5) had the worst feed conversion ratio index (1.70).

Within this context, it can be inferred that the MOS and $\beta$-manananase enzyme may play an important role in circumstances where the use of antibiotics is not desired. However, broilers subjected to the $\beta$-manananase + MOS interaction can worsen their performance, demonstrating a possible antagonism between substances or changes in villus in the absorptive portion of the chickens' gastrointestinal tract (O'NEILL et al., 2014).

The results of weight at slaughter $(\mathrm{kg})$ and relative weights (\%) of the carcass, prime cuts, edible offal, and abdominal fat of broilers at 42 days of age differed significantly $(\mathrm{P}<0.05)$ among treatments, except for the weight of breast and liver (Table 3 ).

The broilers fed with basal diet without growth promoter $+\beta$-mannanase + MOS (T5) had the lowest absolute weight $(2.942 \mathrm{~kg})$ at slaughter compared to the other birds. This result may be due to the antagonism between $\beta$-mannanase and the MOS or to the fact that MOS had positive effects on the intestinal mucosa and immune system, thus reducing the colonization of pathogenic bacteria and causing better productive performance and carcass yield. Similar results were obtained by WALDROUP et al. (2003), who tested MOS-based prebiotics in broiler diets and saw an improvement in the broilers' performance.

The broilers subjected to treatment 3 (basal feed without growth promoter $+\beta$-mannanase) had the best carcass yield $(89.79 \%)$, while those with treatment 2 (basal feed without growth promoter) had the lowest carcass yield $(88.70 \%)$. These results corroborate those obtained by ALBINO et al. (2006), who tested antibiotics and MOS-based prebiotics in broiler diets and observed better broiler carcass yield.

No significant difference $(\mathrm{P}>0.05)$ was observed among treatments evaluated for breast yield of the broilers. These results were similar to those obtained by SOUZA et al. (2008), who did not find a better breast yield in broiler chickens fed with diets containing MOS and enzymatic complex. On the other hand, ALBINO et al. (2006), assessing the addition of MOS in broilers at 42 days of age, found significant differences in the breast yield of the broilers.

Basal feed without growth promoter + MOS (T4) produced the best yield for drumsticks (13.64\%),

Table 3 - Effect of $\beta$-mannanase and mannan oligosaccharides on values of slaughter weight and relative weight of carcass, prime cuts, edible offal, and abdominal fat of broilers at 42 days of age.

\begin{tabular}{|c|c|c|c|c|c|c|}
\hline Variables & Positive Control (T1) & Negative Control (T2) & $\beta$-mannanase (T3) & $\operatorname{MOS}(\mathrm{T} 4)$ & $\begin{array}{l}\beta \text {-mannanase + } \\
\text { MOS (T5) }\end{array}$ & $\mathrm{CV}(\%)$ \\
\hline Slaughter weight* $(\mathrm{kg})$ & $3.019 \mathrm{ab}$ & $3.032 \mathrm{ab}$ & $3.048 \mathrm{ab}$ & $3.130 \mathrm{a}$ & $2.942 \mathrm{~b}$ & 3.64 \\
\hline Carcass* $(\%)$ & $88.89 \mathrm{ab}$ & $88.70 \mathrm{~b}$ & $89.79 \mathrm{a}$ & $89.38 \mathrm{ab}$ & $89.07 \mathrm{ab}$ & 1.02 \\
\hline Breast $^{\mathrm{ns}}(\%)$ & $34.09 \mathrm{a}$ & $34.08 \mathrm{a}$ & $33.99 \mathrm{a}$ & $33.69 \mathrm{a}$ & $34.13 \mathrm{a}$ & 3.74 \\
\hline Drumstick* $(\%)$ & $13.14 \mathrm{ab}$ & $12.75 \mathrm{bc}$ & $13.21 \mathrm{ab}$ & $13.64 \mathrm{a}$ & $12.14 \mathrm{c}$ & 5.42 \\
\hline Thigh* (\%) & $10.53 \mathrm{~b}$ & $10.48 \mathrm{~b}$ & $10.79 \mathrm{ab}$ & $11.24 \mathrm{a}$ & $10.42 \mathrm{~b}$ & 4.88 \\
\hline Wing* $(\%)$ & $7.91 \mathrm{ab}$ & $7.66 \mathrm{ab}$ & $7.99 \mathrm{a}$ & $8.04 \mathrm{a}$ & $7.52 \mathrm{~b}$ & 4.80 \\
\hline $\operatorname{Liver}^{\mathrm{ns}}(\%)$ & $1.59 \mathrm{a}$ & $1.49 \mathrm{a}$ & $1.65 \mathrm{a}$ & $1.61 \mathrm{a}$ & $1.55 \mathrm{a}$ & 10.25 \\
\hline Heart* $(\%)$ & $0.55 \mathrm{ab}$ & $0.55 \mathrm{ab}$ & $0.56 \mathrm{ab}$ & $0.60 \mathrm{a}$ & $0.52 \mathrm{~b}$ & 11.03 \\
\hline Gizzard* $(\%)$ & $1.20 \mathrm{ab}$ & $1.13 \mathrm{~b}$ & $1.25 \mathrm{a}$ & $1.27 \mathrm{a}$ & $1.19 \mathrm{ab}$ & 8,02 \\
\hline Abdominal fat* $(\%)$ & $0.71 \mathrm{~b}$ & $0.97 \mathrm{a}$ & $0.91 \mathrm{a}$ & $0.91 \mathrm{a}$ & $0.96 \mathrm{a}$ & 17.46 \\
\hline
\end{tabular}

${ }^{1} \mathrm{~T} 1$ - basal feed (Positive Control); T2 - basal feed without growth promoter (Negative Control); T3 - basal feed without growth promoter + $\beta$-mannanase; T4 - basal feed without growth promoter + MOS; T5 - basal feed without growth promoter $+\beta$-mannanase + MOS. * Significant $(\mathrm{P}<0.05)$, by $\mathrm{F}$ test.

Averages followed by different letters in the same line differ significantly according to Duncan's test $(\mathrm{P}<0.05)$. 
thighs (11.24\%), and wings (8.08\%), while treatment 5 (basal feed without growth promoter $+\beta$-mannanase + MOS) had the lowest values, of $12.14 \%, 10.42 \%$, and $7.52 \%$ for drumsticks, thighs, and wings, respectively. Similar results were obtained by ALBINO et al. (2006).

The relative weights for heart $(0.60 \%)$ and gizzard $(1.27 \%)$ were the highest for the broilers that received basal feed without growth promoter + MOS (T4) and the lowest for those that received basal feed without growth promoter $+\beta$-mannanase + MOS (T5).

As for abdominal fat, the lowest index was seen in broilers that received the basal feed, and the highest content was found in broilers who consumed the basal diet without growth promoter + $\beta$-mannanase + MOS (T5). These results corroborate those reported by SOUZA et al. (2008), who found an increase in abdominal fat in broiler chickens fed with enzyme complex. Different results were reported by VARGAS JR. et al. (2000), who used two antibiotics and two types of probiotics and prebiotics in their broiler feed mixes and saw no increase in yield for commercial cuts and edible offal.

It is noteworthy that the MOS may improve growth performance and carcass yield of broiler chickens, because it has a positive effect on the intestinal mucosa and the immune system and reduces colonization of pathogenic bacteria (WALDROUP et al., 2003). However, there is a discrepancy in the results from that study, probably originating from the amount used in the feed, ingredients used in the formulation of feed, the sanitary conditions in which the birds are raised and by differences in experimental design, among other factors (OLIVEIRA et al., 2007).

The results of the economic analysis for the different treatments of broilers at 42 days of age can be seen in table 4 . It was seen that the treatment containing basal diet without growth promoter + MOS (T4) was superior to the others as regards gross revenue, average revenue, and profitability index of the broilers at 42 days of age, and no reduction in body weight was seen due to the replacement of growth promoters by MOS. However, treatment 5 (basal diet without growth promoter $+\beta$-mannanase + MOS), despite making a combination of enzyme and prebiotic available to the birds, did not cause any improvement in performance, being the treatment that had the lowest gross income and, consequently, the worst economic efficiency.

It is clear that the treatment with basal feed without growth promoter (T2) had the best feed economic efficiency. This low feeding cost resulted in an excellent gross margin, relative gross margin, gross revenue, and profitability index, being inferior only to treatment 4 (basal feed without growth promoter + MOS).

The use of prebiotics may be a very attractive alternative since they are more effective, leading to higher profitability, thus meeting the requirements of the most demanding markets that disapprove the use of growth promoters in bird feed. In this respect, it is important to analyze the relative prices of poultry and feed, as well as the fluctuation in the dollar exchange rate so the appropriate replacement can be defined, promoting higher profitability.

The relative gross margin of broilers at 42 days for the treatments containing MOS and $\beta$-mannanase were $5.74 \%$ and $0.99 \%$, respectively, higher compared to the basal diet. However, the diet containing an association of $\beta$-mannanase + MOS produced a $5.45 \%$ lower relative gross revenue than the basal diet.

\section{CONCLUSION}

It was concluded that $\beta$-mannanase and mannan oligosaccharides can replace growth

Table 4 - Effect of $\beta$-mannanase and mannan oligosaccharides on the economic traits of broilers at 42 days of age.

\begin{tabular}{|c|c|c|c|c|c|c|c|c|c|}
\hline Treatment $^{1}$ & $\mathrm{LW}^{2}(\mathrm{~kg})$ & $\mathrm{FI}^{2}(\mathrm{~kg})$ & $\mathrm{FP}^{2}$ (USD) & $\begin{array}{c}\mathrm{FC}^{2} \\
\text { (USD/bird) }\end{array}$ & $\begin{array}{c}\mathrm{GR}^{2,3} \\
\left(\mathrm{USD}_{\text {bird }}{ }^{-1}\right)\end{array}$ & $\begin{array}{c}\mathrm{GM}^{2,3} \\
\left(\mathrm{USD}^{2} \text { bird }^{-1}\right)\end{array}$ & $\begin{array}{c}\mathrm{RGM}^{2,3} \\
(\%)\end{array}$ & $\begin{array}{c}\mathrm{AP}^{2,3} \\
(\%)\end{array}$ & $\mathrm{RPI}^{2,3}(\%)$ \\
\hline 1 & 3.064 & 5.073 & 0.466 & 2.364 & 4.473 & 2.109 & 100.00 & 89.21 & 100.00 \\
\hline 2 & 3.104 & 5.016 & 0.466 & 2.337 & 4.531 & 2.194 & 104.03 & 93.88 & 105.23 \\
\hline 3 & 3.114 & 5.118 & 0.472 & 2.416 & 4.546 & 2.130 & 100.99 & 88.16 & 98.82 \\
\hline 4 & 3.150 & 5.083 & 0.466 & 2.369 & 4.599 & 2.230 & 105.74 & 94.13 & 105.52 \\
\hline 5 & 2.984 & 5.006 & 0.472 & 2.363 & 4.357 & 1.994 & 94.55 & 84.38 & 94.59 \\
\hline
\end{tabular}

${ }^{1} \mathrm{~T} 1$ - basal feed; T2 - basal feed without growth promoter; T3 - basal feed without growth promoter + $\beta$-mannanase; T4 - basal feed without growth promoter + MOS; T5 - basal feed without growth promoter $+\beta$-mannanase + MOS.

${ }^{2}$ LW - live weight; FI - feed intake; FP - feed cost; FC - feeding cost; GR - gross revenue; GM - gross margin; RGM - relative gross margin; AP - average profitability; RPI - relative profitability index.

${ }^{3}$ Price of the poultry on September $27^{\text {th }} 2011$ : USD $1.46 \mathrm{~kg}^{-1}$. 
promoters in broiler diets without compromising the productive performance and economic efficiency. However, the association of these products in the diet may cause negative interaction, reducing the performance of broilers.

\section{REFERENCES}

ALBINO, L.F.T. et al. Uso de prebióticos à base de mananoligossacarídeo em rações para frangos de corte. Revista Brasileira de Zootecnia, v.35, n.3, p.742-749, 2006. Available from: <http://www.scielo.br/pdf/rbz/v35n3/30064.pdf >. Accessed: nov 12, 2012. doi: 10.1590/S1516-35982006000300015.

ARRUDA, E.M.F. et al. Evaluation of diets with enzyme complex on broiler performance. In: PSA ANNUAL MEETING, 2013, San Diego, California, USA. Proceedings... Champaign, IL: Poultry Science Association, 2013. v.92, suppl.1. p.114.

BUFFINGTON, D.E. et al. Black globe humidity index (BGHI) as comfort equation for dairy cows. Transactions of the SAE, v.24, p.711-714, 1981

CARAMORI JR., J.G. Efeito de simbiótico na ração inicial de frangos de corte sobre o desempenho, qualidade de carcaça e carne. Acta Scientiarum Animal Sciences, v.30, n.1, p.17-23, 2008. Available from: <http://periodicos.uem.br/ojs/index.php/ ActaSciAnimSci/article/view/3595>. Accessed: jan 19, 2013. doi: 10.4025/actascianimsci.v30i1.3595

ESONU, B.O. et al. Effect of enzyme supplementation on the performance of broiler finisher fed Microdesmis puberula leaf meal. International Journal of Poultry Science, v.3, n.2 p.112114, 2004. Available from: 〈http://www.pjbs.org/ijps/fin132.pdf〉. Accessed: nov 12, 2012. doi: 10.3923/ijps.2004.112.114.

GODOI, M.J.S. et al. Utilização de aditivos em rações formuladas com milho normal e de baixa qualidade para frangos de corte Revista Brasileira de Zootecnia, v.37, n.6, p.1005-1011, 2008. Available from: <http://www.scielo.br/pdf/rbz/v37n6/ v37n6a08.pdf >. Accessed: nov 12, 2012. doi: 10.1590/S151635982008000600008 .

LORENÇON, L. et al. Utilização de promotores de crescimento para frangos de corte em rações fareladas e peletizadas. Acta Scientiarum Animal Sciences, v.29, n.2, p.151-158, 2007. Available from: <http:// periodicos.uem.br/ojs/index.php/ActaSciAnimSci/article/view/219>. Accessed: jan 19, 2013. doi: 10.4025/actascianimsci.v29i2.219.

OLIVEIRA, M.C. et al. Utilização de nutrientes de dietas contendo mananoligossacarídeo e/ou complexo enzimático para frangos de corte. Revista Brasileira de Zootecnia, v.36, n.4, p.825-831, 2007. Available from: <http://www.scielo.br/pdf/rbz/ v36n4/11.pdf >. Accessed: nov 12, 2012. doi: 10.1590/S151635982007000400011

O'NEILL, H.V.M. et al. Multicarbohydrase enzymes for nonruminants. Asian-Australasian Journal of Animal Science, v.27, n.2, p.290-301, 2014. Available from: <http://www.ajas.info/ upload/pdf/ajas-27-2-290-17.pdf >. Accessed: feb 20, 2014. doi: 10.5713/ajas.2013.13261

OPALINSKI, M. et al. Adição de complexo enzimático e da granulometria da soja integral desativada melhora desempenho de frangos de corte. Ciência Rural, v.40, n.3, p.628-632, 2010. Available from: <http://www.scielo.br/pdf/cr/v40n3/ a476cr962.pdf>. Accessed: feb 15, 2013. doi: 10.1590/S010384782010005000017

ROCHA, A.P. et al. Prebióticos, ácidos orgânicos e probióticos em rações para frangos de corte. Revista Brasileira de Saúde e Produção Animal, v.11, n.3, p.793-801, 2010.

ROSTAGNO, H.S. et al. Tabelas brasileiras para aves e suínos Composição de alimentos e exigências nutricionais. 3.ed. Viçosa, MG: Editora UFV, 2011. 252p.

SIMS, M.D. et al. Effects of dietary mannan oligosaccharide, bacitracin methylene disalicylate, or both on the live performance and intestinal microbiology of turkeys. Poultry Science, v.83, n.7, p.1148-1154, 2004. Available from: <http://ps.oxfordjournals.org/ content/83/7/1148.full.pdf+html $>$. Accessed: feb 15, 2013. doi: $10.1093 / \mathrm{ps} / 83.7 .1148$

SOUZA, R.M. et al. Efeitos da suplementação enzimática e da forma física da ração sobre o desempenho e as características de carcaça de frangos de corte. Ciência e Agrotecnologia, Lavras, v.32, n.2, p. 584-590, 2008. Available from: <http://www.scielo. br/pdf/cagro/v32n2/37.pdf>. Accessed: feb 15, 2013. doi: 10.1590/ S1413-70542008000200037.

VARGAS JR. et al. Uso de probióticos e prebióticos em rações de frangos de corte. Revista Brasileira de Ciência Avícola, Supl.2, p.31, 2000

WALDROUP, P.W. et al. Utilization of Bio-Mos ${ }^{\circledR}$ mannan oligosaccharide and Bioplex ${ }^{\circledR}$ copper in broiler diets. International Journal of Poultry Science, v.2, n.1, p.44-52, 2003. Available from: <http://www.pjbs.org/ijps/fin52.pdf>. Accessed: feb 15, 2013. doi: 10.3923/ijps.2003.44.52.

ZOU, X.T. et al. Effect of $\beta$-mannanase (Hemicell) on growth performance and immunity of broilers. Poultry Science, v.85, n. 12, p.2176-2179. 2006. Available from: <http://ps.oxfordjournals.org/ content/85/12/2176.full.pdf+html>. Accessed: feb 15, 2013. doi: $10.1093 / \mathrm{ps} / 85.12 .2176$. 